\title{
Sulphur Forms Distribution in Soil Profiles of Different Locations of Southwestern Nigeria
}

\author{
${ }^{1,2}$ Oseni, O. A., ${ }^{1}$ Adeoye, G. O., ${ }^{1}$ Orimoloye, J. O., ${ }^{2}$ Taiwo, A. G. and \\ ${ }^{2}$ Shoyemi,O. S. \\ ${ }^{I}$ Department of Agronomy, University of Ibadan, Ibadan, Oyo-State, \\ ${ }^{2}$ Department of Science Laboratory Technology, Chemistry Unit, Moshood Abiola Polytechnic, Abeokuta, Ogun \\ State, Nigeria.
}

\begin{abstract}
Non-sulphur nitrogen fertilizer use, soil profile, $p H$ and physico-chemical properties contribute to soil sulphur deficiency so distribution of different forms of sulphur in soil profiles of twelve locations in Ogun and Oyo states, Southwestern Nigeria was investigated to know their status with respect to the soil depths of samples derived from sedimentary and igneous/metamorphic rocks comprising of Alfisols (8 profiles) and Ultisols (4 profiles). These were collected at four different soil depths of $0-20 \mathrm{~cm}, 20-40 \mathrm{~cm}, 40-60 \mathrm{~cm}$ and 60 $80 \mathrm{~cm}$ respectively from savanna and forest vegetation zones. The soil physico-chemical properties of $\mathrm{pH}$, organic carbon, total nitrogen, CEC, clay, silt and sand were determined using standard analytical methods and correlated with the different forms of sulphur (available, organic and total). The results showed that both the available, organic and the total $S$ were positively correlated with these parameters $\left(r=0.905^{* *}\right)$ and $(r=$ $\left.0.590^{* *}\right)$ respectively. The status of the different forms of $S$ fell below the critical limits of $10 \mathrm{mg} / \mathrm{kg}$ and as a result, farmers are advised to apply sulphur-containing fertilizers in these soils so as to obtain maximum yields in their crops particularly for leguminous plants.
\end{abstract}

Keywords: Distribution, forms of Sulphur, Soil profiles, Alfisols, Ultisols, Vegetation zones, Correlation and Critical limits.

\section{Introduction}

The continued use of non-sulphur nitrogen fertilizer in soils of Nigeria had contributed to sulphur deficiency problem, particularly since rainfall is not a major source of soil sulphur in this country ${ }^{(1,2)}$. The results of earlier studies carried out on Southwestern Nigerian soils have shown that sulphur deficiency occurs in some Nigerian soils ${ }^{(2,3,4)}$. However, the degree of the sulphur deficiency as well as the parameters for ascertaining the requirement must be determined as the basis for evaluating the status of soil sulphur adequacy and fertilization requirement of soils ${ }^{(5)}$. Sulphur status varies with the depth depending upon the soil $\mathrm{pH}$ and physico-chemical properties of the soil ${ }^{(6)}$. Also, several soil factors influence the availability of sulphur and hence, the status of different forms of sulphur in soils varies widely with soil type ${ }^{(7)}$. There is little or no information available regarding the status of sulphur in these soils, the present study was carried out to investigate the different forms of sulphur in relation to some soil depths and characteristics of twelve different locations in Southwestern Nigeria.

\section{Materials And Methods}

\subsection{Sample Collection And Preparation}

Soil samples $(0-20 \mathrm{~cm}, 20-40 \mathrm{~cm}, 40-60 \mathrm{~cm}$ and $60-80 \mathrm{~cm})$ depths, derived from igneous/metamorphic and sedimentary rocks were collected in twelve locations in Southwestern Nigeria from forest and savanna vegetation zones as shown in Table 1.

\subsection{Physico-Chemical Analysis}

The samples were analyzed for $\mathrm{pH}$ in 1:1 soil to water slurry. The soil organic carbon was determined by the chromic acid digestion, the soil total nitrogen was determined by macro-kjeldal method, exchangeable cations were extracted with neutral $1 \mathrm{~N} \mathrm{NH}_{4} \mathrm{OAc}, \mathrm{Ca}^{2+}$ and $\mathrm{Mg}^{2+}$ in the extracts were analyzed using an Atomic Absorption Spectrophotometer (AAS) while $\mathrm{K}^{+}$and $\mathrm{Na}^{+}$were determined by a Flame Photometer. The soil CEC was estimated as the sum of the exchangeable cations, the particle size was determined by $\mathrm{KCl}$ and $\mathrm{NH}_{4} \mathrm{OAc}$ ( $\mathrm{pH}$ 4.8) respectively, the available $\mathrm{S}$ was extracted using $\mathrm{Ca}\left(\mathrm{H}_{2} \mathrm{PO}_{4}\right)_{2}$ and determined turbidimetrically as $\mathrm{BaSO}_{4}{ }^{(8)}$. The total organic $\mathrm{S}$ was converted to $\mathrm{SO}_{4}-\mathrm{S}$ according to the 'reverse $\mathrm{S}$ ' ${ }^{(9)}$ and determined turbidimetrically as $\mathrm{BaSO}_{4}$, total - $\mathrm{S}$ was converted to $\mathrm{SO}_{4}-\mathrm{S}$ by the ignition method ${ }^{(10)}$ and determined turbidimetrically as $\mathrm{BaSO}_{4}$. 
Simple correlations and multiple regressions were calculated between forms of sulphur and soil properties by adopting standard statistical procedures.

\section{Result and Discussion}

The general characteristics of the soils samples, the range and the mean values of the physico-chemical properties of soils as well as the distribution of the forms of $S$ in the soils investigated are presented in the Tables 1, 2 and 3 respectively. Two main types of soils occur in twelve different locations considered which are Alfisol and Ultisol. The mean $\mathrm{pH}$ values of most locations were fairly acidic with the exception of Ilaro and Omi-Adio which were considered to be neutral. Owode-Egba soil had the highest organic carbon deposition $(2.00 \mathrm{~g} / \mathrm{kg})$ with lowest concentration of $0.77 \mathrm{~g} / \mathrm{kg}$ found at Ishaga-Orile soil. The highest Organic carbon obtained for Owode-Egba soil could be attributed to the forest vegetation therein which resulted in huge litter fall as well as the rate of organic matter decomposition due to the activity of the soil microorganisms. Also, the rate of litter fall is very low in Ishaga-Orile soil which contributed to its low organic carbon content of the soil since the location is within the savanna vegetation zone.

Owode-Egba soil had the highest total nitrogen content of $8.67 \mathrm{~g} / \mathrm{kg}$ which was followed by Omi-Adio soil with $6.29 \mathrm{~g} / \mathrm{kg}$. However, the lowest concentration of this parameter of $2.01 \mathrm{~g} / \mathrm{kg}$ was found at Ibara-Orile soil. The highest CEC of $3.10 \mathrm{Cmol} / \mathrm{kg}$ was found at Ishaga-Orile soil whereas the lowest value of 1.19 $\mathrm{Cmol} / \mathrm{kg}$ was observed for Ifo soil. It is interesting to note that higher percentages of sand were obtained in nearly all the locations investigated with the exception of Abeokuta soil that had $43.43 \%$ of sand but with the highest percentage of clay of $42.75 \%$.

Distribution of different forms of S showed increasing trend with depth in both Alfisols and Ultisols. Available $\mathrm{S}$ in the surface soil of Alfisol and Ultisol ranged from 0.13 to 1.06 and 0.26 to $1.03 \mathrm{~g} / \mathrm{kg}$ with the mean values of 0.68 and $0.62 \mathrm{mg} / \mathrm{kg}$ respectively.

On the other hand, the organic $S$ in the surface soil of both the Alfisol and Ultisol ranged from 0.10 to 0.80 and 0.10 to $0.13 \mathrm{mg} / \mathrm{kg}$ with the mean values of 0.22 and $0.18 \mathrm{mg} / \mathrm{kg}$ respectively. However, the total $\mathrm{S}$ in the surface soil of these two soil orders ranged from 0.23 to 1.82 and 0.36 to $1.34 \mathrm{mg} / \mathrm{kg}$ with the mean values of 0.94 and $0.79 \mathrm{mg} / \mathrm{kg}$ respectively. Higher amounts of total $\mathrm{S}$ in the sub-surface soils than in the surface soil could be attributed to percolation through the soil horizon by osmosis with subsequent organic matter accumulation and decomposition. It increased down the depth in both orders being highest at 60-80 $\mathrm{cm}$ depth. This may be attributed to high carbon content at lower horizons, which is also evident from the fact that total $\mathrm{S}$ showed highly significant coefficient of correlation with organic carbon (Alfisols and Ultisols $\mathrm{r}=0.905^{* *}$ ). Total S appears to be a function of soil organic matter as both are significantly and positively correlated. This is similar to the results obtained by Trivedi et al., 2000. It also showed positively relationships with $\mathrm{pH}$, organic carbon, total nitrogen, CEC, Clay, Silt and Sand contents in both orders as in Table 4. These results were similar to the findings of Sharma and Bremner, (1972).

In multiple regression studies, the available $S$ showed significant and negative regression coefficients with silt $(b=-0.570 ;-9.400$ and -9.281$)$ respectively whereas both the total and organic $\mathrm{S}$ showed significant and positive regression coefficients with silt $(b=5.788 ; 4.965$ and 4.420$)$ respectively. Similar regression coefficients were obtained for both clay and sand particles. However, the available $\mathrm{S}$ showed both negative significant and positive regression coefficients with $\mathrm{pH}$ in multiple regression studies $(\mathrm{b}=-0.003 ; 1.455$ and 1.481) respectively whereas the total $S$ showed significant and negative regression coefficients $(b=-0.956$ and 1.138) respectively but the organic $S$, on the other hand showed significant and positive regression coefficient $(b=0.979)$.

The multiple regression studies for the CEC showed significant and negative regression coefficients with available $S(b=-0.129 ;-1.403$ and -1.396$)$ respectively whereas both the total $S$ and organic $S$ showed significant and positive regression coefficients $(b=0.835 ; 0.790$ and 0.243$)$ respectively. The reverse was the result found for organic carbon in its multiple regression studies in which case the available $\mathrm{S}$ showed both negative and positive significant regression coefficients $(b=-0.042 ; 1.053$ and 1.048$)$ respectively while the total $S$ and organic $S$ showed negative significant regression coefficients $(b=-0.718 ;-0.678$ and -0.214$)$ respectively. The available $S$ and organic $S$ showed positive significant regression coefficients $(b=0.427$; $1.336 ; 1.387$ and 1.889 ) respectively in multiple regression studies for the total $\mathrm{N}$, the total $\mathrm{S}$ however, showed negative significant regression coefficients $(b=-0.596$ and -0.948$)$ for the same parameter investigated.

Available, Organic and Total sulphur contents increased with increase in depth. At sub-surface (20-40 $\mathrm{cm}$ ), the contents in both soils were more or less similar, whereas available sulphur found in deeper layers were less than the critical limit of $10 \mathrm{mg} / \mathrm{kg}$. Consequently, these soils can be considered as marginal in available $\mathrm{S}$ status.

Generally, $\mathrm{pH}$ had positive correlation with all forms of sulphur. This may be best interpreted to mean that the presence of $\mathrm{H}^{+}$and $\mathrm{OH}^{-}$ions on the soil complex in which case the $\mathrm{H}^{+}$ions attract $\mathrm{SO}_{4}{ }^{2-}$ ion thereby 
resulting in its availability in the soil. Positive correlation of different forms of sulphur with organic carbon, total nitrogen and CEC indicates that the organic matter serves as a reservoir of sulphur ${ }^{(13,14)}$.

\section{Conclusion}

The result obtained shows that sulphur status, irrespective of its forms in the soils of the twelve locations investigated, increased down the soil profile as the depth increases. Also, soil properties examined contributed positively to the different forms of sulphur in the soils of locations, however, the contents of the sulphur could not meet the required level for optimum yield of most leguminous crops so, farmers are advised to apply sulphur-containing fertilizer in the soils of locations investigated particularly for leguminous crops.

Table 1: General Characteristics of the Soils Samples

\begin{tabular}{|l|l|l|l|l|}
\hline Soil No & Location & Parent material & Vegetation zone & Soil order \\
\hline 1 & Abeokuta & Igneous/Metamorphic & Forest & Alfisol \\
\hline 2 & Owode-Egba & Igneous/Metamorphic & Forest & Ultisol \\
\hline 3 & Ishaga-Orile & Igneous/Metamorphic & Savanna & Ultisol \\
\hline 4 & Ibara-Orile & Igneous/Metamorphic & Savanna & Ultisol \\
\hline 5 & Ayetoro & Sedimentary & Savanna & Ultisol \\
\hline 6 & Papalanto & Sedimentary & Savanna & Alfisol \\
\hline 7 & Ilaro & Sedimentary & Forest & Alfisol \\
\hline 8 & Ifo & Sedimentary & Forest & Alfisol \\
\hline 9 & Eruwa & Igneous/Metamorphic & Forest & Alfisol \\
\hline 10 & Omi-Adio & Igneous/Metamorphic & Forest & Alfisol \\
\hline 11 & Idi-Ose & Igneous/Metamorphic & Forest & Alfisol \\
\hline 12 & Oyo & Igneous/Metamorphic & Savanna & Alfisol \\
\hline
\end{tabular}

Table 2: Range and Mean values of Physico-chemical properties of Soil

\begin{tabular}{|c|c|c|c|c|c|c|c|c|c|c|c|c|c|c|}
\hline \multirow[t]{2}{*}{ Location } & \multicolumn{2}{|c|}{ pH } & \multicolumn{2}{|c|}{$\begin{array}{l}\text { Organic Carbon } \\
\text { (gkg) }\end{array}$} & \multicolumn{2}{|c|}{ 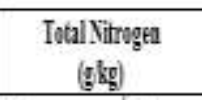 } & \multicolumn{2}{|c|}{$\begin{array}{l}\text { CEC } \\
\text { (Crollgg) }\end{array}$} & \multicolumn{2}{|c|}{$\begin{array}{l}\text { Clyy } \\
\text { (9i) }\end{array}$} & \multicolumn{2}{|c|}{$\begin{array}{l}\text { 3iit } \\
\text { (yi) }\end{array}$} & \multicolumn{2}{|c|}{$\begin{array}{l}\text { Sand } \\
\text { (vi) }\end{array}$} \\
\hline & Range & Mean & Range & Mean & Rangt & Nean & Rarge & Nean & Ruget & Уean & Range & Jean & Ranget & Mean \\
\hline Abroduts & $390-6.75$ & 538 & $050-1.50$ & 0.81 & $1.12-399$ & 280 & $106-2.59$ & 1.61 & 36.0046 .00 & 42.75 & 3.70 .31 .40 & 13.78 & $32.60-50.30$ & 43.43 \\
\hline Onode-Egons & $590-7.60$ & 630 & $124-3.05$ & 200 & $7.01-11.98$ & 8.67 & $206-2.61$ & 230 & 9.40-17.40 & 1288 & $5.45-9.40$ & 6.40 & 85.20 & 8073 \\
\hline Lhagn--0rite & $480-5.88$ & 551 & $0.60-0.88$ & 0.77 & 2.174 .62 & 3.47 & 267.3 .80 & 3.10 & $1.40-10.00$ & 6.05 & 6.0222 .00 & 1225 & $72.60-92,60$ & 81.70 \\
\hline Itarn-0rile & $5.69-6.45$ & 593 & $0.60-1.04$ & 0.80 & 1.612 .273 & 201 & 21992.260 & 2.64 & 840.560 & 5.55 & $\mathrm{NI}$ & 3.40 & $9100-91.20$ & 9115 \\
\hline Avetoro & 4.67 .5 .50 & 5.17 & $094+1.32$ & 109 & 4.134 .76 & 4.45 & $156-3.36$ & 200 & $4.00-25.00$ & 1288 & $5.95-13.40$ & 9.47 & $60.60-90.60$ & 77.65 \\
\hline Papalanto & $536-8.26$ & 651 & 41.18 & 100 & $2.66+41$ & 3.34 & $257-3.02$ & 2.82 & 11..42-13.40 & 1225 & $11.40-17,40$ & 14.15 & 7320.81 .20 & 7610 \\
\hline Ihro & $6.42-7.78$ & 704 & 090-1.04 & 100 & $1.75+20$ & 2.49 & $209-221$ & 2.14 & $5.40-11.40$ & 7.70 & 290.21 .40 & 1020 & $67.20-89.70$ & 8210 \\
\hline Ifo & 467.6068 & 539 & $050-1.72$ & 124 & $3.71-532$ & 4.64 & 050.228 & 1.19 & $8.60-3260$ & 2295 & 5.42-17.00 & 9.10 & $59.0-84.0$ & 67.75 \\
\hline Eruma & $532-6.22$ & 5.79 & $0.48-1.32$ & 0.87 & 1.82 .259 & 2.19 & $220-2.47$ & 2.31 & $4.00-14.00$ & 7.50 & $3.52-18.00$ & 9.83 & $78.00-90.60$ & 8268 \\
\hline Oni-Adio & 6.69 .7 .26 & 704 & $0.74+2.00$ & 134 & $2.03-14.50$ & 629 & $220-2 \pi$ & 250 & $1.40-27.40$ & 9.70 & $4.00-14.00$ & 795 & $58.60-94.60$ & 8235 \\
\hline Iit-0se & $6.48-6.84$ & 6.68 & 050-1..4 & 104 & $1.75-12.40$ & 5.10 & $245-3.17$ & 2.76 & $1.40-13.40$ & 7.35 & $7.40-12.60$ & 9.75 & $79.20-87.20$ & 8290 \\
\hline Oro & $605-7.07$ & 656 & 0.14 .1 .54 & 100 & $1.95-11.00$ & 4.55 & 212.2 .58 & 2.33 & $0.60-10.60$ & 3.85 & $12.40-15.40$ & 13.40 & $78.00-860.00$ & 8275 \\
\hline
\end{tabular}

Table 3: Distribution of different forms of Sulphur $(\mathrm{mg} / \mathrm{kg})$

\begin{tabular}{|c|c|c|c|c|c|c|}
\hline \multirow[t]{2}{*}{ Average depth (cm) } & \multicolumn{2}{|c|}{ Available - S } & \multicolumn{2}{|c|}{ Organic - S } & \multicolumn{2}{|l|}{ Total - S } \\
\hline & Range & Mean & Range & Mean & Range & Mean \\
\hline \multicolumn{7}{|l|}{ Alfisols (8 profiles) } \\
\hline $0-20$ & $0.13-1.06$ & 0.68 & $0.10-0.80$ & 0.22 & $0.23-1.82$ & 0.94 \\
\hline $20-40$ & $0.28-1.09$ & 0.75 & $0.04-0.29$ & 0.17 & $0.23-1.38$ & 0.92 \\
\hline $40-60$ & $0.39-1.18$ & 0.85 & $0.10-0.51$ & 0.29 & $0.29-1.99$ & 1.14 \\
\hline $60-80$ & $0.39-1.39$ & 0.98 & $0.13-1.19$ & 0.41 & $0.52-2.28$ & 1.40 \\
\hline \multicolumn{7}{|l|}{ Ultisols (4 profiles) } \\
\hline $0-20$ & $0.26-1.03$ & 0.62 & $0.10-0.31$ & 0.18 & $0.36-1.34$ & 0.79 \\
\hline $20-40$ & 0.24-1.09 & 0.71 & $0.10-0.27$ & 0.14 & $0.34-1.36$ & 0.86 \\
\hline $40-60$ & $0.66-1.09$ & 0.91 & $0.23-0.72$ & 0.37 & $0.79-1.48$ & 1.12 \\
\hline $60-80$ & $0.83-1.63$ & 1.12 & $0.13-0.30$ & 0.21 & $0.98-1.76$ & 1.33 \\
\hline
\end{tabular}

Table 4: Coefficients of Correlation between different forms of Sulphur and Soil properties

\begin{tabular}{|l|l|l|l|l|l|l|l|l|}
\hline Forms of S & pH & Organic - C & Total - N & CEC & Clay & Silt & Sand \\
\hline Alfisols and Ultisols \\
\hline Available - S & $0.905^{* *}$ & $0.905^{* *}$ & $0.905^{* *}$ & $0.905^{* *}$ & $0.905^{* *}$ & $0.905^{* *}$ & $0.905^{* *}$ \\
\hline Organic - S & $0.590^{*}$ & $0.590^{*}$ & $0.590^{*}$ & $0.590^{*}$ & $0.590^{*}$ & $0.590^{*}$ & $0.590^{*}$ \\
\hline Total - S & $0.905^{* *}$ & $0.905^{* *}$ & $0.905^{* *}$ & $0.905^{* *}$ & $0.905^{* *}$ & $0.905^{* *}$ & $0.905^{* *}$ \\
\hline
\end{tabular}




\section{Significant coefficient of correlation $*$ and $* *$}

Table 5: Regression Coefficients between different forms of Sulphur and Soil properties

\begin{tabular}{|l|l|l|l|l|l|l|l|l|}
\hline Forms of S & pH & Organic - C & \multicolumn{1}{l|}{ Total - N } & \multicolumn{1}{l|}{ CEC } & Clay & Silt & Sand \\
\hline Alfisols and Ultisols & \multicolumn{5}{|l|}{} \\
\hline Available - S & 0.003 & -0.042 & 0.427 & -0.129 & -14.471 & -0.570 & 13.773 \\
& 1.455 & 1.053 & 1.336 & -1.403 & -18.374 & -9.400 & 25.575 \\
& 1.481 & 1.048 & 1.387 & -1.396 & -18.688 & -9.281 & 25.762 \\
& & & 1.887 & & & & \\
\hline Organic - S & 0.979 & -0.718 & 0.429 & 0.835 & -11.665 & 5.788 & 6.913 \\
& & -0.678 & 1.336 & 0.790 & & 4.965 & \\
& & -0.214 & 1.387 & 0.243 & & 4.420 & \\
\hline Total - S & & 1.889 & & & & \\
& -0.956 & -0.718 & -0.596 & 0.835 & 2.558 & 5.788 & -7.736 \\
& -1.138 & -0.678 & -0.948 & 0.790 & 4.731 & 4.965 & -9.024 \\
\hline
\end{tabular}

\section{References}

[1]. Bromfield (1974). The deposition of sulphur in the Rain Water in Northern Nigeria. Tellus, 26(3), 408 - 411.

[2]. Fox R. L., Kang B. T. and Nangju D. (1977). Sulphur requirements of cowpea and implications for production in the tropics. Agronomy Journal, 69; 201-205.

[3]. Kang B. T. and Osiname A. O. (1976). Sulphur responses of maize in Western Nigeria. Argon J. 68: 333-336.

[4]. Osiname O. A. and Kang B. T., (1977). Effect of Sulphur sources on maize yield in an Entisol in Western Nigeria. Nigeria Agric. J., 14: 37-39.

[5]. Adetunji M. T. and Adepetu J. A. (1989). Sulphur fertilization requirements of Southwestern Nigerian Soils. Ife Journal of Agriculture. 11(1 and 2), 20-31.

[6]. Bhatnagar R. K., Bansal K. N. and Trivedi S. K. (2003). Distribution of sulphur in some profiles of Shivpuri district of Madhya Pradesh. Journal of the Indian Society of Soil Science 51,74-76.

[7]. Balangoudar S. R. and Satyanarayana T. (1990). Journal of the Indian Society of Soil Science. 38; 641

[8]. A.O.A.C. (2005). Official Methods Analysis of the Association of Official Analytical Chemists. $16^{\text {th }}$ Edition, Washington, DC30033.

[9]. Bardsley C. E. and Lancaster J. O. (1960). Proc. Soil Science Society, American. 24; 265

[10]. Steinbergs A., Lisma O., Freney J. R. and Barrow N. J. (1962). Determination of total sulphur in soil and plant material. Analytical Chemists Acta. 27; 158

[11]. Trivedi S. K., Bansal K. N., Tomar R. A. and Verma R. S. (2000). Journal of Indian Society of Soil Science. 48; 238.

[12]. Sharma V. K. and Bremner J. M. (1972). Journal of Indian Society of Soil Science. 45; 480.

[13]. Agboola A. A. and Corey R. B. (1972). Nitrogen content deficiency survey and maize in Eastern Nigeria. Nigeria Journal of Science. 10(1): $1-18$.

[14]. Tabatabai M. and Bremmer J. M. (1972). Soil Sci. 114; 380 